\title{
How Are Company Size, Financial Performance and Corporate Governance Related to Directors' Remuneration?
}

\author{
Norziana Lokman ${ }^{1} \&$ Fattiadriati Mohd Tareh ${ }^{2}$ \\ ${ }^{1}$ Accounting Research Institute (ARI), Universiti Teknologi MARA, Malaysia \\ ${ }^{2}$ Faculty of Administrative Science and Policy Studies, Universiti Teknologi MARA, Malaysia \\ Correspondence: Norziana Lokman, Accounting Research Institute (ARI), Universiti Teknologi MARA, Malaysia.
}

Received: July 29, 2020

doi:10.5430/rwe.v11n6p12
Accepted: October 1, 2020

Online Published: October 8, 2020

URL: https://doi.org/10.5430/rwe.v11n6p12

\begin{abstract}
This study examined the relationship between the company-specific characteristics, namely, company size, company performance, and company leverage and the corporate governance attributes of a company which includes CEO duality and remuneration committee independence as the predictor factors that determine directors' remuneration. A sample of 260 public listed companies on Bursa Malaysia was selected using stratified random sampling for the financial reporting of 2018. All data concerning the company characteristics and corporate governance attributes were obtained from the annual reports of the companies, which can be accessed from the Bursa Malaysia website. Pearson correlation and multi-regression analysis were used to analyse the data to determine the relationship of the predictor variables with director remuneration. On the one hand, the results of the study showed that directors' remuneration is positively and significantly related to the size of the company. On the other hand, the financial performance of a company is positively but weakly related to directors remuneration. The remaining predictors have no relationship with directors' remuneration. The finding suggested that the key determinant factor of directors' remuneration is company size whereas company performance may have a small impact. Lastly, company compliance with the recommendation of the Malaysian Code on Corporate Governance did not guarantee the effectiveness of the monitoring function of the remuneration committee in ensuring that directors' remuneration is commensurate with company performance. The result of the study provides additional evidence and support that company size and financial performance are linked to director remuneration. Also the finding of the study reconfirmed prior study that board leadership structure (CEO duality) and remuneration committee independent have no impact on directors' remuneration.
\end{abstract}

Keywords: company size, financial performance, director remuneration, company characteristics, corporate governance

\section{Introduction}

The remuneration and benefits of directors in publicly listed companies (PLCs) have become two of the main controversial topics in corporate governance over the years (Kabir, 2008). Criticism by the public and media on the directors' remuneration started in the early 1990s. Headlines, such as 'Fat Cats in the Dock' (Economist, 1995) and 'Derailing the Gravy Train' (Sunday Times, 1995) criticised the increase in directors' pay which does not correspond with the company performance. Decades later, the public still raise their concerns on the excessive pay received by directors and top management, which is not link to the performance and continued to increase despite the companies are failing (BBC News, 2012; Viviers, 2015). The public is also concerned with the wide gap between directors and top management's pay and that of average employees and the complexity in determining the right remuneration package for the directors (BBC News, 2012). The complexity in determining the right package is one of the reasons that make determining and regulating directors' remuneration difficult (Ndzi, 2016; 2017).

Haron and Akhtaruddin (2013) reported that the average directors' remuneration in 2005 was RM2.88 million, which showed an increase of $100 \%$ more with than the average directors' remuneration of RM1.09 million in 2000 recorded by Abdullah (2006). In a recent report issued by KPMG, titled 'KPMG Report on Non-Executive Directors' Remuneration 2017', indicates that the average non-executive directors' (NEDs) remuneration was approximately RM162,000, which is a 33\% increase from the average NEDs' remuneration recorded in 2013 of RM122,000. The continuous increase of directors' remuneration, which does not correspond with the increase in company performance, has attracted attention from the public and investors. Therefore, identifying the determinant factors of 
directors' remuneration is a topic relevant to stakeholders and policymakers. It also provides an interesting setting to examine the level of directors' remuneration and investigating potential predictors for determining directors' remuneration. Numerous issues have been raised by shareholders, investors and stakeholders regarding directors' remuneration and company performance specifically in Malaysia, some of which are presented below.

Bumi Armada Berhad, at its Nineteenth Annual General Meeting held on $8^{\text {th }}$ June 2015, was questioned by the Minority Shareholder Watchdog Group (MSWG) on the significant increase of the total directors remuneration paid from RM16 million in 2013 to RM23.12 million in 2014. The increase was mainly due to the payment made to executive directors which had doubled from RM5.9 million in 2013 to RM12.15 million in 2014. The detailed remuneration breakdown of each director was not disclosed in Bumi Armada's 2014 annual report. Shareholders questioned the increase of remuneration for directors despite the drop in the net profit of the company by $49.28 \%$ compared with its financial, which ended on $31^{\text {st }}$ December 2013 (The Sundaily, $9^{\text {th }}$ June 2015).

During the seventh annual general meeting of Sapura Energy Berhad (Sapura), the Employees' Provident Fund (EPF), one of the institutional investors of Sapura, raised their dissatisfaction with the remuneration paid to Sapura's President and Chief Executive Officer, Tan Sri Shahril Shamsuddin. The remuneration, which amounted to RM71.92 million for the financial year of 2018, was considered as excessive, especially given the company was experiencing losses. However, it was revealed later that his remuneration was tied to the shares covenant that he had with financial institutions related to the company refinancing exercise (The Star, 21 ${ }^{\text {st }}$ July 2018; Khoo, 2018; Zakariah, 2018). However, this explanation was not included in the annual report, which resulted in the dissatisfaction of shareholders. These two circumstances show that issues of dissatisfied shareholders on directors' remuneration have been a continuous challenge. Listed companies need to find the right balance between providing the right remuneration package that would attract the best talents and convincing the shareholders on the logic of the remuneration packages given.

Surveys conducted on directors' remuneration have identified that the primary concern of shareholders is whether the compensation paid to the directors is aligned with the interest of the shareholders (Murphy, 1999; Core et al. 2001). In the early 80s, majority of the study concentrated on proving the connection between executive pay and company performance (Herdan et al., 2011). Agency theory proposes that directors remuneration is one of the possible tools to align the interest of the management and shareholders. However, the empirical evidence is inconsistent and can be categorised into three possible outcomes. The first outcome observed a strong connection between company performance and directors' remuneration (Haron and Akhtaruddin, 2013; Amin et al., 2014). In contrast, the second outcome found a weak relationship (Dogan and Smyth, 2002; Hassan et al., 2003). The third outcome, found no significant relationship between directors remuneration and company performance (Abdullah, 2006). The inconsistency of the findings showed that directors' remuneration is not necessarily determine by the company performance.

The other possible factors that determine directors remuneration include the company size (Abdullah, 2006; Herdan et al., 2011), age (Abed et al., 2014) and level of risk or leverage of the company (Amin et al., 2014). Research by Amin et al. (2014), found that company-specific characteristics are significant in determining the level of directors remuneration and that the company's corporate governance structure can also influence the directors remuneration packages. This finding, however, contradicts the findings by Haron and Akhtaruddin (2013), which found that the sole determinant of directors' remuneration is the specific attributes of the company, including firm size, leverage and performance. According to Haron and Akhtaruddin (2013), the corporate governance does not influence remuneration, indicating a positive sign of corporate culture in Malaysia, which depends on the economic factors rather than the internal control of the board.

This study aims to determine the level of directors' remuneration of Malaysian PLCs and to examine the relationship between directors' remuneration and the company's size, performance, leverage, and specific corporate governance characteristics. Using a sample of 260 Malaysian companies, this study finds that the level of directors' remuneration is at a moderate level. Further, the study also documents a positive relationship between company size and financial performance with directors remuneration.

The study contributes to the literature by providing the recent level of directors' remuneration of Malaysia PLCs after the revision of the MCCG 2017. Next, the results of the study provide additional support to the argument that company size can influence directors' remuneration. Larger companies are assumed to have the resources and ability to offer better and more attractive remuneration package to their directors. Moreover, larger companies generally have a complex structure which requires more monitoring. As such larger companies are expected to pay higher remuneration to directors. Finally, the study also contributes to providing evidence that company financial 
performance, to some extent influences the remuneration of executive directors. Also, the study result reconfirms further that corporate governance has no impact on directors remuneration. This study is different from prior studies because the independence of remuneration committee is included as one of the corporate governance attributes that determine directors' remuneration.

The rest of the paper proceeds as follows. Section 2 presents corporate governance development in Malaysia. Section 3 reviews the relevant literature and discuss the hypotheses development. Section 4 describes the data and research methodology, while section 5 highlights the analysis and key results of the study. Finally, section 6 provides a conclusion and suggestions for future research.

\section{Corporate Governance Requirements about Directors Remuneration in Malaysia}

The recommendation for disclosure of directors' remuneration was first introduced in the Cadbury Report in 1992. The report suggested the formation of a remuneration committee, which would provides a full and clear statement of director benefits and the disclosure on the total remuneration paid, which separates the salary and performance-related elements. Later, the Greenbury Committee was established in 1995 by the Confederation of British Industry (CBI) as a response to the growing concern on the remuneration level paid to directors and senior executives in PLCs in the UK. Headed by Sir Richard Greenbury, the Committee was requested to conduct a study on directors' remuneration to identify good practices in determining directors' remuneration and to prepare a code of practice for UK PLCs. The Greenbury Committee established a guideline in setting the level of directors' remuneration, which includes a suggestion on the mechanism to link directors' remuneration with performance and improve the transparency and accountability in the procedures.

Since the introduction of the first Malaysian Code on Corporate Governance (MCCG) 2000 in Malaysia, one of the main issues that have been highlighted and needed to be improved is the need for companies to have proper governance in determining directors' remuneration. The Securities Commission (SC) issued the MCCG (Revised 2007) to enhance the best practices in corporate governance further, including the separation of the roles of the Chairman and the CEO; the composition of independent non-executive directors and the establishment of nomination, remuneration and audit committees. The code was revised by the issuance of the MCCG 2012, again focusing on enhancing board effectiveness on the basis of eight broad principles and recommendations, which include strengthening the composition of nomination and remuneration committees and establishing formal and transparent remuneration policies and procedures. Superseding the earlier MCCG codes, MCCG 2017 now promotes the internalisation of corporate governance culture, which also highlights directors' remuneration, whereby it recommends that directors' remuneration be linked to the individual performance of directors. The remuneration should be determined through the independent process, and the remuneration package offered should be able to attract, retain and motivate the best people to be on board.

The MCCG 2017, together with the latest Bursa Malaysia Listing Requirement (BMLR) has required PLCs to disclose detailed information of directors' remuneration on an individual basis. Although none of the governance codes have outlined the procedures on how to determine the best remuneration package, the recent disclosure required under MCCG 2017 and BMLR is made to promote enhance corporate transparency and improve the confidence of investors. Given the relatively recent reformed to MCCG 2017 in relation to directors' remuneration disclosure and independent of remuneration committee members. This study aims to determine the level of directors' remuneration of Malaysian PLCs and to examine the relationship of the directors' remuneration with the company size, performance, leverage, and specific corporate governance attributes of the PLCs.

\section{Literature Review and Hypotheses Development}

\subsection{Level of Directors' Remuneration}

Director is a person appointed by shareholder or board of directors. Director is recognized as an officer of a company that has a significant role in directing and leading the company towards a set of goal. The Companies Act 2016 spelled out that a director has a statutory and fiduciary duties towards its shareholders. It is the directors' responsibility to monitor the management behaviour. The BMLR made it mandatory for all listed companies to have a sufficient number of board members which consist of both executive directors and non-executive directors (NEDs) on the board who are compensated for their services. Remuneration of director is commonly consists of basic salary, bonus, fees, benefits and other form of monetary and non-monetary values including stock options (Dah and Frye, 2017). Unfortunately, little is known about the level of directors' remuneration and whether company size and financial performance directly related to directors remuneration.

The amount paid to directors has attracted widespread attention from the Malaysian public and investors. An on-going 
debate argues over how much directors and senior management should be paid and what factors are considered in determining the remuneration packages. In 2015, Bumi Armada Berhad was criticised by its shareholders during its annual general meeting when the payments made to its executive directors had increased by more than double from RM5.9 million in 2013 to RM12.15 million in 2014 despite the company reporting a loss for the financial year of 2014. Recently, another discontentment by shareholders during the annual general meeting was on the excessive remuneration received by the President and CEO of Sapura amounting to RM71.92 million, which is equivalent to 35\% of the net profit of the company for 2018.

With the increasing disclosure requirements and an increase in shareholder activism, PLCs are in constant review by the shareholders and investors especially on the level of remuneration paid to directors, which should be linked to performance. The new BMLR and MCCG 2017 requires all listed companies to set up an attractive remuneration package and disclose details about directors' remuneration. It is suggested that a company should fix commensurate remuneration to attract and retain a credible pool of directors. Previously disclosure requirement on details of directors' remuneration is not mandatory in Malaysia; consequently, there is a high possibility that directors are being paid higher than reported in annual reports. Indeed, Ghasemi and Ab Razak (2020) documented a trend that companies increases executive remuneration for nine years from 2006 to 2014. This study proposed that with the new revision to MCCG and BMLR concerning disclosure of directors' remuneration, the level of director remuneration among PLCs in Malaysia is expected to be at a high level. Thus, this study hypothesises that:

H1: The level of directors' remuneration in Malaysian PLCs is high.

\subsection{Company Size}

For company size, the study used book value of the total asset to measure the size of a company. This measurement is one of the most common and popular techniques used by prior studies (Dang et al. 2018; Jaafar and James, 2013; Haron and Akhtaruddin, 2013; Graham et al. 2012; Herdan et al. 2011). Dang et al. 2018 suggested that total asset is more relevant to be used for research about directors' remuneration compared to other measurements. Generally, larger companies have complicated operations, business environment and decision making. The directors and managers managing large companies are expected to have the superior skills, knowledge and experience to handle the job complexity. As such, large companies need to offer high remuneration package that would attract or retain the right talents. Furthermore, larger companies are assumed to have high agency problem and information asymmetry. Thus, larger companies may require more monitoring compared to smaller companies. Additionally, larger companies are also expected to have better resources and capability to offer high remuneration to their directors.

The previous empirical study generally found a strong positive relationship between company size and directors' remuneration. Firth et al. (1999) found that the key determinants for directors' remuneration in Hong Kong companies is the size of the company. On the basis of a study of the 100 highest market capitalisation companies listed on the London Stock Exchange, Herdan et al. (2011) found that directors' remuneration is positively related to the size of the company. Similarly, Abdullah (2006) found that firm size is positively associated with directors' remuneration in Malaysia. He stated that large firms naturally pay high remuneration to compensate for the quantity of work and complication of the work involved. His findings are also supported by the study conducted by Haron and Akhtaruddin (2013) on 120 Malaysian PLCs. They found that firm size is positively related to directors' remuneration. Amin et al. (2014) also observed the same result, as they documented that large companies pay high remuneration to their directors. In addition, Jaafar and James (2013) found a positive relationship between the size of the company on executive remuneration on the basis of 537 companies listed on the main board of Bursa Malaysia from 2007 to 2009.

Prior research on directors' remuneration has generally argued that firm size is the most significant factor in determining directors' remuneration. Directors and executives in larger companies receive higher remuneration with than those in smaller firms, as they have a more complex tasks, financial matters and difficult decision making (Jensen \& Murphy, 1990). Company size is the key determinant factor of senior executive remuneration and changes in remuneration payments in Hong Kong companies (Firth et al. 1999). Consistent results were also found in Canadian companies where the company size is linked to the pay that the CEOs receives in Canadian companies. Yatim (2012) found that firm size and growth opportunity significantly influence the directors' remuneration, as a larger firm typically has a larger board, and the quantum of its remuneration is also higher.

In addition, a higher-growth firm is also more likely to provide more incentive-based remuneration than low-growth firms. Amin et al. (2014) also found that the most significant factor in determining executives' remuneration is the company size. They suggested that directors managing larger companies also expect high remuneration packages considering the complexity in decision making, considerable responsibilities and high expectations. Lee and Isa (2015) examined the relationship between the directors' remuneration, firm performance and corporate governance of the 
banking sector in Malaysia. They found that directors' remuneration is positively related to bank size, and foreign banks perform better than domestic banks despite the relatively lower pay received by their directors. Therefore, this study hypothesises that:

$\mathrm{H} 2$ : Company size is the most significant determinant factor of directors' remuneration

\subsection{Company Performance}

Agency theory argues that directors' remuneration should be congruent with company performance. However, some inconsistencies have been observed in the findings of prior studies that examine the relationship between the firm performance and directors' remuneration. Dogan and Smyth (2002) examined a sample of Malaysian PLCs from 1989 to 2000 and found a positive correlation between board remuneration and firm performance. A study conducted by Hassan et al. (2003) showed a weak positive relationship between directors' remuneration and company performance. A study conducted by Hassan et al. (2003) showed a weak positive relationship between directors' remuneration and compant performance in Malaysian PLCs during the Asian financial crisis from 1996 to 1997. Haron and Akhtaruddin (2013) found that firm performance positively affects directors' remuneration. Furthermore, Amin et al. (2014) reported that a company with higher profitability pays higher remuneration to its directors. However, Abdullah (2006) found that profitability is not the key factors in determining directors' remuneration of both distressed and non-distressed companies in Malaysia.

Studies in developed countries also have observed inconsistent findings in the relationship between the performance of the company and directors' remuneration. Firth et al. (1999) found that pay-for-performance compensation schemes are not the key factors in setting top management remuneration in Hong Kong. The same result was also found in the Netherlands (Duffhues and Kabir, 2008). These results suggest that the companies should use other incentives to align the interest of shareholders with that of managers to resolve agency problems. In contrast, Zhou (2000) observed a significant positive relationship between the board remuneration and the performance of Canadian companies. In a similar vein, Herdan et al. (2011) discovered that a positive association exists between the return on equity (ROE) of firms and directors' remuneration. On the basis of the above discussion, most of the previous studies have supported the agency theory claim, which states remuneration should be sensitive to performance to motivate the directors or increase the efforts of managers. Thus, the study proposes that:

H3: A positive relationship exists between directors' remuneration and company financial performance.

\subsection{Company Leverage}

Jensen and Meckling (1976) stated that agency theory assumes managers to be more risk-averse than shareholders. Managers and directors that manage higher-risk companies expect to receive higher remuneration than those in lower-risk companies as compensation for their willingness to face the insecurity of the company's returns. The risk here is associated with the level of leverage of the company. However, higher leverage limits the ability of the company to pay a higher amount of remuneration. Besides, high leverage companies indicate that they may need more monitoring (Dah and Frye, 2017). In contrast, debt can also serve as an effective monitoring mechanism. This double roles might be the reason why empirical studies on the relationship between leverage and directors' remuneration produced mix results.

Studies by Chen (2006) and Miller et al. (2002) showed a positive relationship between the risk and remuneration of a company. Haron and Akhtaruddin (2013) also found that the leverage of the company positively affects directors' remuneration. However, Amin et al. (2014) reported that leverage has an insignificant effect on directors' remuneration on the basis of the study of a panel of 845 companies from 2009 to 2011. Ghasemi and Razak (2020) found that the remuneration of executive directors is negatively associated with the leverage of the company. Although directors in high-leveraged companies assumed high risks and should receive high compensation, the amount of remuneration is also tied to the leverage of the company (Elloumi and Gueyie, 2001). Thus, the level of leverage in a company considerably influences directors' remuneration. As such, the next hypothesis is as follows:

H4: A positive relationship exists between directors' remuneration and the leverage of the company.

\subsection{CEO Duality}

By having a duality structure, the CEO cum Chairman may have a strong influence over the board in designing the remuneration structure, which creates a conflict of interest between the management and the shareholders. Core et al. (1999) recorded that CEO remuneration increases when the CEO also chairs the board. Their result is consistent with the findings of Elloumi and Gueyie (2001) and Muslu (2005), where the compensation of the CEO in a CEO duality structure is higher than that in a unitary leadership structure. To enhance the independence of the board in the context 
of Malaysia, the MCCG recommended that the position of the Chairman and CEO be separated to avoid concentration of power and conflict of interest. The separation of the position of CEO and chairman may help avoid the management from making decisions for their own benefit. Abdullah (2004) and Haron and Akhtaruddin (2013) found that CEO duality in Malaysia, does not have a significant impact on directors' remuneration. The contradictory result may be due to the different regulatory framework and corporate norms in Malaysian corporations. As such, no concrete evidence has been found to suggest that CEO duality is related to directors' remuneration. Therefore, the following hypothesis is proposed:

\section{H5: Directors' remuneration is related to CEO duality}

\subsection{Remuneration Committee Independence}

Prior studies state that an important aspect in the corporate governance structure is the independence of the board. (Core et al.,1999; Chen, 2006). Jensen (1990) suggested that inside directors are prone to be biased towards the suggestions of the CEO. According to the findings by Dahya et al. (2008), having an independent board improves the effectiveness in monitoring the management. Meanwhile, Core et al. (1999) found that outside directors improve the effectiveness in setting pay-performance. Therefore, by having outside directors, decisions by the board are more independent and protect the interest of shareholders.

Most governance reports, such as the Cadbury Report, Greenbury Report, and the MCCG recommend the inclusion of independent directors as one of the governance mechanisms that can reduce agency cost especially in relation to the establishment of the remuneration committee. The composition of the remuneration committee plays an essential role in ensuring independent remuneration policies and packages. By having independent members, the remuneration committee can better exercise their supervisory power in monitoring the management. Thus, the remuneration packages set by the remuneration committee is aligned with the interest of the shareholders.

Remuneration committee independence (i.e., an independent chairperson and a majority of independent directors on the board) is almost universally viewed as a desirable corporate governance practice (Nelson et al. 2010). A proactive board dominated by independent NEDs deliver an effective corporate governance performance against self-serving executive directors (Pearce and Zahra, 1991). This structure is supported by an empirical study carried out by Lee and Isa (2015), where they found that the directors' remuneration is positively related to the percentage of independent directors and performance of banks in Malaysia. However, Chen (2006) found that NEDs may not be necessarily independent. Daily et al. (1998) found no evidence to support that the independent compensation committee affects executive pay, which is inconsistent with the agency theory argument. Given that the issue of excessive CEO compensation has raised general public awareness, the level of compensation paid should be more subtle and not be overly excessive.

The recent introduction of MCCG 2017 recommends that the board of listed companies establish a remuneration committee that consists wholly of NEDs. Having an independent remuneration committee may influence the board in setting the right remuneration package and thus avoid excessive remuneration. Therefore, the next hypothesis is:

H6: Directors' remuneration and the independence of the Remuneration Committee are related.

\section{Methodology}

\subsection{Sample}

The main market has 801 PLCs as of $31^{\text {st }}$ December 2018. Foreign companies, banks and financial institutions listed in Bursa Malaysia are excluded from the population of study because of the different governance framework and different company practices and regulations. After exclusion of the above institutions, the remaining eleven sectors that are included in this study are construction, consumer products, energy, healthcare, industrial products and services, plantation, property, technology, telecommunication and media, transportation and logistics and utilities, with a total of 747 companies.

The final sampled selection is non-random as companies that did not submit their annual report for the financial year in 2018 are excluded from the study. Moreover, companies with financial periods that exceed or are less than 12 months due to changes in the financial year-end are also excluded from the sample. The financial year ending in 2018 is selected because of the newly revised MCCG 2017, which recommends a detailed disclosure on the named basis for the remuneration of individual directors. In addition, Bursa Malaysia also amended its listing requirement on 29 November 2017, which required listed issuers to publish their Corporate Governance Report (CG Report). From the total sampled companies, only 260 companies are selected following the proportional stratified sampling method. Table 1 shows 11 categories of industrial classification of the final sampled companies. 
Table 1. Industrial classification of final sampled companies

\begin{tabular}{lccc}
\hline Industry type & $\begin{array}{c}\text { Total Number } \\
\text { of Listed } \\
\text { Companies }\end{array}$ & $\begin{array}{c}\text { Industry } \\
\text { \% }\end{array}$ & $\begin{array}{c}\text { No of Companies } \\
\text { for Sampling }\end{array}$ \\
\hline Construction & 49 & 7 & 17 \\
Consumer products & 179 & 24 & 62 \\
Energy & 32 & 4 & 11 \\
Healthcare & 14 & 2 & 5 \\
Industrial products and services & 227 & 30 & 79 \\
Plantation & 43 & 6 & 15 \\
Property & 101 & 14 & 35 \\
Technology & 38 & 5 & 13 \\
Telecommunication and Media & 19 & 3 & 7 \\
Transportation and Logistics & 32 & 4 & 11 \\
Utilities & 13 & 2 & 5 \\
\hline TOTAL & 747 & 100 & 260 \\
\hline
\end{tabular}

\subsection{Source of Data and Variables Measurement}

The data from this study are collected from the annual report and the corporate governance report of the selected sample. Both documents are public documents that can be retrieved from the Bursa Malaysia website and the websites of these respective companies. The total assets, total liabilities, total equity, and earnings after tax can be obtained from the Statement of Financial Position and Comprehensive Income of the companies. Meanwhile, the remuneration of executive directors and NEDs can be found from the Corporate Governance Statement and also from the Notes to the Financial Statements in the Annual Reports. Details on the members of the remuneration committee and the application of the separation of CEO/Chairman positions can be found in the Corporate Information in the annual reports and as disclosed in Practice 1.3 of the Corporate Governance Report.

The list of variables and measurements used in the study is presented in Table 2. All of the measurement tools are selected on the basis of prior studies. Then, the data collected are analysed using a descriptive statistic, correlation and regression analysis. Additional tests such as sensitivity test are also run to ensure that the results produced are robust.

Table 2. Description of variables and measurement

\begin{tabular}{|c|c|c|}
\hline Variables & Measurements & Citation \\
\hline $\begin{array}{l}\text { Directors Remuneration } \\
\text { (DREM) }\end{array}$ & $\begin{array}{l}\text { Total Directors' Remuneration }=\text { The } \\
\text { total compensation received by directors } \\
\text { during the year (Salary + Bonus }+ \text { Fees }+ \\
\text { Benefits + Others monetary value) }\end{array}$ & $\begin{array}{l}\text { Herdan et al. (2011), } \\
\text { Haron and Akhtaruddin } \\
\text { (2013), Ya'acob (2016) }\end{array}$ \\
\hline Company Size (CSZE) & $\begin{array}{l}\text { Book value of total Assets (TA) is equal } \\
\text { to Non-current assets plus Current assets } \\
\text { as disclosed in the statement of financial } \\
\text { position. }\end{array}$ & $\begin{array}{l}\text { Anderson and Reeb } \\
\text { (2003), Herdan et al. } \\
\text { (2011), Jaafar and James } \\
\text { (2013), Ghasemi and Ab } \\
\text { Razak (2020) }\end{array}$ \\
\hline $\begin{array}{l}\text { Company Performance } \\
\text { (CPRF) }\end{array}$ & $\begin{array}{l}\text { Return on Asset (ROE) during the period. } \\
\text { ROE is used to measure company } \\
\text { performance ROE = Net Income/Total } \\
\text { Equity }\end{array}$ & Herdan et al. (2011) \\
\hline $\begin{array}{l}\text { Company Leverage } \\
\text { (CLVR) }\end{array}$ & $\begin{array}{l}\text { The book value of total debts over book } \\
\text { value of total equity. (Debt to Equity }\end{array}$ & $\begin{array}{l}\text { Jaafar and James } \\
\text { (2013) }\end{array}$ \\
\hline
\end{tabular}




\begin{tabular}{lll}
\hline & ratio) Total debts (liabilities)/Total equity & \\
\hline CEO Duality (CEOD) & Binary Variable & Haron and Akhtaruddin (2013) \\
& CEO Duality: 1; Otherwise: 0 & \\
\hline Independence of & \% of non-executive directors in the & Cybinski and Windsor (2013) \\
Remuneration & Remuneration Committee & \\
Committee (INRC) & Minority non-executive directors or no \\
& remuneration Committee: '0’ \\
& Majority non-executive directors but \\
& less than 100\%: 1 \\
& $100 \%$ non-executive directors: 2 & \\
\hline
\end{tabular}

\section{Results and Analysis}

\subsection{Descriptive Statistics}

Table 3 shows that the average total remuneration received by directors in Malaysian PLCs is RM5,584,863. The range of the total directors' remuneration is from RM299,000 to RM109,141,000 with a standard deviation of RM10,892,937. This result indicates a wide variation of directors' remuneration among companies. Additional analysis was carried out by separating NEDs and executive directors' remuneration, where the results showed that the average remuneration for NEDs and executive directors are RM711,793 and RM4,873,073 respectively. The NEDs' remuneration ranges from RM2,500 to RM10,882,000 with a standard deviation of RM1,156,666. Meanwhile, the executive directors' remuneration ranges from nil (as some companies do not have an executive director) to RM108,218,000 with a standard deviation of RM10,666,470.

Table 3. Directors' remuneration (in RM'000)

\begin{tabular}{lclcc}
\hline & Minimum & Maximum & Mean & Std. Deviation \\
\hline Total NED Remuneration & 2.500 & 10882.00 & 711.793 & 1156.666 \\
Total ED Remuneration & 0.000 & 108218.00 & 4873.073 & 10666.470 \\
Directors Remuneration & 299.000 & 109141.00 & 5584.863 & 10892.937 \\
\hline
\end{tabular}

From the sample data, the directors' remuneration was then divided into three categories: low, moderate and high, as presented in Table 4 below. Table 5 shows the distribution of the companies in accordance with the remuneration level. The result shows that from the sample of 260 companies, the remuneration level of 19 companies is categorised as high, 132 companies pay a moderate amount of directors' remuneration and 105 companies are categorised as low remuneration level.

Table 4. Scale for directors remuneration

\begin{tabular}{ll}
\hline Scale $(\mathbf{R M})$ & Indicator \\
\hline $299,000-3,670,000$ & Low \\
$3,670,001-7,340,000$ & Moderate \\
$7,340,001-11,000,000$ & High \\
\hline
\end{tabular}

Table 5. Level of directors remuneration

\begin{tabular}{llc}
\hline & Frequency & Percentage \\
\hline Low & 106 & 40.8 \\
Moderate & 135 & 51.9 \\
High & 19 & 7.3 \\
Total & 260 & 100.0 \\
\hline
\end{tabular}


This study uses three characteristics of a company, which are the company size, company performance and leverage. Table 6 shows the descriptive statistics of these characteristics. The company size was calculated on the basis of the total assets of PLC. From the descriptive statistic, the mean of the company size of Malaysian PLCs is RM 2,846,431,688. The smallest PLC has its total asset of RM 24,789,000 and the largest has a total of RM71,430,117,000. The standard deviation for company size is RM 7,990,957,132, which shows a high dispersion of company size in the sample.

The performance of companies in this study was measured using ROE, which is an accounting-based performance measure. The findings show that the average ROE is 0.0325 with a high dispersion whereby the minimum ROE was -1.64 to 2.29. Thus, few companies suffered losses during the period of study. Moreover, the results show that the mean of debt to equity (D/E) ratio is 0.9163 with a standard deviation of 1.22 . The minimum and maximum value of the $\mathrm{D} / \mathrm{E}$ ratio is 0.01 and 9.48 , respectively. A good $\mathrm{D} / \mathrm{E}$ ratio is approximately 1 to 1.5 . On average, majority of the companies ( $93 \%$ or 242 ) have a D/E ratio below 2 , and only 18 companies or $7 \%$ have debt ratios over 2 . However, the ideal D/E ratio varies depending on the industry because some industries use more debt financing than other industries. For example, financial and manufacturing industries often have higher ratios that can be greater than 2 .

Table 6. Company characteristics

\begin{tabular}{lcccc}
\hline & Minimum & Maximum & Mean & Std. Deviation \\
\hline Company Size (RM'000) & 24789.000 & 71430117.000 & 2846431.688 & 7990957.132 \\
Company Performance & -1.64 & 2.29 & .0325 & .28314 \\
Leverage & .01 & 9.48 & .9163 & 1.22647 \\
\hline
\end{tabular}

From the total of 260 companies, 228 companies have adopted the MCCG Practice 1.3 on the separation of the Chairman and CEO position while 32 companies still practice the CEO duality. The high level of adoption corresponds with the Corporate Governance Monitor Report 2019, which states that the level of adoption for Practice 1.3 of the MCCG is at $88.6 \%$.

With regards to the independence of the remuneration committee, the companies are categorised either as high-independence or low-independence. A company is considered to have high-independence if the remuneration committee consists of $100 \%$ NEDs. In contrast, a company without a remuneration committee or with a minimum number of NEDs in the remuneration committee is classified as low-independence. Even though the BMLR has not required listed companies to establish a remuneration committee, the MCCG recommended that the Board have a remuneration committee to implement policies and procedures relating to the remuneration of the board and senior management. In addition, MCCG 2017 also recommended that a remuneration committee only consist of NEDs, and a majority of them must be independent.

Table 7 shows that out of 260 companies, about 255 companies (98.1\%) have established a remuneration committee of which 202 companies have a totally independent remuneration committee. From the sample, five (5) companies have not adopted Practice 6.2 of MCCG, where four (4) of the companies have not established a remuneration committee, while one (1) company has an equal number of NEDs and executive directors sitting in its remuneration committee. The remaining 53 companies from the sample has a majority of NEDs in their remuneration committee.

Additional analysis was also done on the sample to determine the adoption level of MCCG Practice 7.1 on the disclosure of directors' remuneration on a named basis. According to the data collected, $89.6 \%$ of the companies have complied with the recommendation of the MCCG. This result also corresponds with the Corporate Governance Monitor Report 2019, which states that the level of adoption for Practice 7.1 of the MCCG is at $89.1 \%$.

Table 7. Corporate governance characteristics

\begin{tabular}{llcc}
\hline Variables & & Frequency & Percentage \\
\hline CEO Duality & Separation & 228 & 87.7 \\
& Duality & 32 & 12.3 \\
& Total & 260 & 100.0 \\
\hline RC & Minority NED/No RC & 5 & 1.9
\end{tabular}




\begin{tabular}{llcc}
\hline Independence & & & \\
& Majority NED & 53 & 20.4 \\
& 100\% NED & 202 & 77.7 \\
& Total & 260 & 100.0 \\
\hline Disclosure on & Departure & 27 & 10.4 \\
named basis & Applied & 233 & 89.6 \\
& Total & 260 & 100.00 \\
\hline
\end{tabular}

\subsection{Correlations Analysis}

The correlation analysis result shows that the company size has a strong positive correlation to directors' remuneration $(r=0.660, p<0.001)$. Next, the company performance has a weak positive relationship with the value of $r=0.292$ and $p<0.001$. Company leverage also shows a weak positive relationship with $r=0.237$. Meanwhile, all the variables under corporate governance characteristics, namely, CEO duality and remuneration committee independence have an insignificant negative relationship with directors' remuneration. Thus, the result suggests that company characteristics are the key determinants of directors' remuneration and that the corporate governance characteristics have no significant influence in determining directors' remuneration (refer to Table 8).

Table 8. Pearson correlation

\begin{tabular}{lccccc}
\hline Variables & CSZE & CPRF & CLVR & CEOD & RCIN \\
DREM & $.660^{* *}$ & $.292^{* *}$ & $.237^{* *}$ & -.066 & -.015 \\
**. Correlation is significant at the 0.01 level (2-tailed). & & & \\
*. Correlation is significant at the 0.05 level (2-tailed).
\end{tabular}

\subsection{Model Specification and Multiple Regression Results}

The relationship between company and corporate governance attributes with directors' remuneration has been tested using the following model:

$$
\text { DREM }=\alpha+\beta 1 \text { CSZE }+\beta 2 \text { CPRF }+\beta 3 \text { CLVR }+\beta 4 \text { CEOD }+\beta 5 \text { RCIN }+\varepsilon
$$

The dependent variable in the model is directors' remuneration (DREM), and this variable is measured by the total directors' remuneration. Company characteristics and corporate governance attributes are the independent variables used in the study. For company characteristics, variables such as company size (CSZE), company performance (CPRF) and leverage (CLVR), are predicted to influence the directors' remuneration. The corporate governance attributes consist of CEO duality (CEOD) and remuneration committee independence (RCIN).

Before the above regression model is run, the researchers have to carry out numerous test to fulfil the underlying regression assumption. The tests are normality test, linearity test, error term test, heteroscedasticity test, and multicollinearity test. Results of these tests showed that there is no issue with normality, linearity, endogeneity, heteroscedasticity and multicollinearity.

Table 9 shows the influence of company characteristics and board attributes on directors' remuneration. The value of $R$ square is 0.457 , which means that $45.7 \%$ of the independent variables used in this study contributes to the determination of directors' remuneration that can be explained by the model. Meanwhile, $F$ statistics determines whether the proposed relationship between the dependent variable and the independent variables is statistically reliable and can be useful to make the predictions and explanations of the model. Table 10 shows the analysis of variance (ANOVA). The results indicate the $F$ ratio of 42.831 at the significance level of 0.001 . The $F$ statistics should be greater than one (1) for the regression model to be considered as a good model (Field, 2013). Thus the regression model of the study is a good fit. 
Table 9. Model summary of the study

\begin{tabular}{cccccc}
\hline $\begin{array}{c}\text { Mode } \\
\mathbf{l}\end{array}$ & $\mathbf{R}$ & $\begin{array}{c}\mathbf{R} \\
\text { Square }\end{array}$ & $\begin{array}{c}\text { Adjusted R } \\
\text { Square }\end{array}$ & $\begin{array}{c}\text { Std. Error of the } \\
\text { Estimate }\end{array}$ & Durbin-Watson \\
\hline 1 & $.676^{\mathrm{a}}$ & .457 & .447 & .33112 & 1.823 \\
\hline
\end{tabular}

a. Predictors: (Constant), CSZE, CPRF, CLVR, CEOD, RCIN

b. Dependent Variable: DRN

Table 10. Analysis of variance (ANOVA)

\begin{tabular}{|c|c|c|c|c|c|c|}
\hline \multicolumn{2}{|c|}{ Model } & $\begin{array}{c}\text { Sum of } \\
\text { Squares }\end{array}$ & df & $\begin{array}{c}\text { Mean } \\
\text { Square }\end{array}$ & $\mathbf{F}$ & Sig. \\
\hline \multirow[t]{3}{*}{1} & Regression & 23.479 & 5 & 4.696 & 42.831 & $.000^{\mathrm{b}}$ \\
\hline & Residual & 27.848 & 254 & .110 & & \\
\hline & Total & 51.327 & 259 & & & \\
\hline
\end{tabular}

a. Dependent Variable: DRN

Predictors: (Constant), CSZE, CPRF, CLEV, CEOD, RCIN.

By referring to Table 11, the coefficient for company size (CSZE) is positive and significant, indicating that the larger the size of a company, the higher the amount of directors' remuneration. This finding is consistent with Amin et al. (2014) and Cybinski and Windsor (2013) who observed that company size significantly influences directors' remuneration, thus supporting hypothesis $\mathrm{H} 2$. As for company performance (CPRF), the coefficient shows a positive significant but weak relationship with directors' remuneration, which indicates that the more profit made by the company, the better remuneration paid to directors. A similar result is also evident when a test is run on executive directors' remuneration. This finding supports hypothesis $\mathrm{H} 3$ and is consistent with the study by Ozkan and Dong (2008). Meanwhile, the coefficient of the company leverage (CLEV) is negative and insignificant, which suggest that leverage does not influence directors' remuneration. In addition, the coefficient of CEO duality (CEOD) is positive and insignificant. This finding is consistent with the studies by Nyambia and Hamdan (2018) and Haron and Akhtaruddin (2013), which revealed that CEO duality does not influence directors' remuneration. The result for remuneration committee independence (RCIN) shows that the coefficient is negative and not significant, which means that the involvement of independent directors in the remuneration committee does not effects directors' remuneration. This result is consistent with the study by Hearn (2013), which suggested that the lack of genuine independent NEDs monitors executive directors effectively. However, when directors remuneration is separated from the executive directors, a positive relationship is evident (please refer to Table 12). This finding is consistent with the studies of Daily et al. (2017), Goh and Gupta (2016), Jaafar and James (2013) and Cybinski and Windsor (2013), which suggested that independent directors can provide better monitoring to reduce conflicts of interest concerning executive directors' remuneration.

Table 11. Summary of multiple regression analysis for directors' remuneration

\begin{tabular}{|c|c|c|c|}
\hline Model & Beta & $\mathbf{t}$ & Sig. \\
\hline (Constant) & & 4.711 & .000 \\
\hline CSZE & .639 & 12.232 & .000 \\
\hline CPRF & .148 & 3.099 & .002 \\
\hline CLVR & -.027 & -.530 & .597 \\
\hline CEOD & .015 & .325 & .745 \\
\hline RCIN & -.018 & -.384 & .701 \\
\hline
\end{tabular}

a. Dependent Variable: DREM

To test the robustness of the result, the study runs two separate multi-regression analysis by replacing the total directors' remuneration with the total NEDs' remuneration and the total executive directors (EDs) remuneration. The 
results can be used to compare the influence of the company specific-characteristics and corporate governance attributes on the remuneration of NEDs and EDs. Table 12 below shows the coefficient statistics for both NEDs and EDs of the sample.

Table 12. Results of multiple regression analysis for NED and ED directors' remuneration

\begin{tabular}{lcc}
\hline & NEDs Remuneration & EDs Remuneration \\
\cline { 2 - 3 } & $\begin{array}{c}\text { Standardizsed } \\
\text { Coefficients } \\
\text { Beta }\end{array}$ & Standardised Coefficients \\
\hline (Constant) & $.589^{*}$ & Beta \\
CSZE & .093 & $.584^{*}$ \\
CPRF & .021 & $.182^{*}$ \\
CLVR & -.077 & .022 \\
CEOD & $.138^{*}$ & .023 \\
RCIN & & -.020 \\
\hline
\end{tabular}

*Significant at 0.01

The results remain consistent for both types of directors with the total directors' remuneration, as it indicates that company size is still the most significant determinant of NEDs and EDs' remuneration. The results show that company size is positively significant at the 0.01 level for NEDs and executive directors' remuneration with coefficient Beta of 0.589 and 0.584 , respectively.

The company performance shows a weak positive relationship with the remuneration of executive directors at a low coefficient Beta of 0.182 but significant at $p<0.01$. This result is consistent with the finding for the total directors' remuneration earlier. However, company performance has no significant relationship with NEDs' remuneration. Remuneration committee independence has a weak positive relationship with NEDs' remuneration at a Beta value of 0.138 at the 0.01 significant level but insignificant with executive directors' remuneration.

\section{Discussion and Conclusion}

The main objective of this study is to determine the factors that influence directors' remuneration in Malaysian PLCs for the financial year of 2018. The study reveals the following findings. Firstly, the level of directors' remuneration in Malaysian PLCs is at a moderate level. Secondly, company size is the most influential factor that affects directors' remuneration. Secondly, company performance seems to have a minor influence on directors' remuneration, which confirm the arguments of specific stakeholders that this remuneration does not reflect the company financial performance. Thirdly, company leverage is insignificant in determining directors' remuneration. Fourthly, the findings also indicate that having a CEO duality structure has no significant effect in determining directors' remuneration. The findings further suggest that having an independent remuneration committee, which entirely consists of NEDs does not guarantee that the directors' remuneration corresponds with the company's performance.

The study contributes to the emerging literature on determining the directors' remuneration in two ways. Firstly, it provides important information on the current level of directors' remuneration in Malaysia PLCs, specifically after the introduction of the new MCCG 2017. Surprisingly corporate governance attributes have no significant impact on the directors' remuneration, which is in contrast to prior studies conducted in developed countries. The differences in the legal and governance framework, and cultural factors may contribute to the insignificant results. Secondly, the findings of this study can facilitate the company in setting the right level of directors' remuneration with the size of the company. A larger company normally requires candidates to be more agile and proactive to match with the complexity and challenges that the company presents. As such, offering adequate amount of remuneration has the potential to retain and attract a pool of candidates with the right qualities to lead and guide the company to achieve its goals. Larger company is expected to offer higher remuneration since larger company has high agency problems and high information asymmetry which require more monitoring from directors. The right kind of remuneration packages can also provide incentives and prevent directors from being involved in fraud and misappropriate behaviour. Moreover, the remuneration committee has to ensure that the total remuneration is linked to the financial performance of the company as well as the individual directors' performance. This connection is important to address the concern of 
stakeholders on the high remuneration for directors, which do not reflect the overall performance of the company.

In addition, the findings of this study do not support the initiatives proposed by MCCG in enhancing the corporate governance policies and practices surrounding the issues of directors' remuneration. MCCG highlighted the importance of having an independent remuneration committee and having a more independent board, which would ensure that remuneration packages are determined based on the merit, qualification, competency and consideration of personal and company performance and competitive market rate. The findings of this study do not show the evidence on the effectiveness of having an independent board and establishing an independent remuneration committee in determining directors' remuneration. However, with the recommendation for detailed disclosures on remuneration policy and remuneration on a named basis, this study provides the current level of disclosure practice and directors remuneration in Malaysia PLCs.

The main limitation of the current study is endogeneity problem. The study has carefully selected the appropriate proxy for each variable to minimise the problem. However, some unobservable characteristic of company and corporate governance attributes related to a director may affect the result (Coles and Li, 2019; 2020). This study also has few other limitations and requires further analysis to enhance its scope, research method and variables included as the predictors in this work. Therefore, future research should fulfil the loopholes in this study. Firstly, the scope of the study may be extended the same study to small and medium enterprise (SMEs) companies, Secondly, to use primary data such as interview and questionnaire or a combination of both. Thirdly, future research may also use different measurement instrument to measure company size and firm performance. In this study the total asset is used to measure the company performance, other techniques that can be used, namely, sales and number of employees. Fourthly, the determining factors may also include individual directors' qualification, experience and skills.

In conclusion, this study is important because it contributes to the knowledge of effective corporate governance monitoring mechanisms on directors' remuneration. Although the findings showed only the significant influence of company size and company performance, an increase in awareness is observed in the importance of good corporate governance practices, especially with regards to directors' remuneration among PLCs. Furthermore, the effect of MCCG recommendations relating to the independence of the remuneration committee and the disclosure of directors' remuneration on a named basis and the level of directors' remuneration are interesting points to examine. Thus, the findings of this study should shed lights to researchers, practitioners, and policymakers on the importance of company size, performance and corporate governance in determining the pay level of directors.

\section{References}

Abdullah, S. N. (2006). Directors' remuneration, firm's performance and corporate governance in Malaysia among distressed companies. Corporate Governance, 6(2), 162-174. https://doi.org/10.1108/14720700610655169

Abed, S., Suwaidan, M., \& Slimani, S. (2014). The Determinants of Chief Executive Officer Compensation in Jordanian Industrial Corporations. International Journal of Economics and Finance, 6(12), 110-118. https://doi.org/10.5539/ijef.v6n12p110

Amin, J., Kamarudin, K., Ismail, W., \& Sarman, S. (2014). What determines directors' remuneration in Malaysia?. In Meen, T-H., Prior, S., \& Lam, K-T. (Eds.), Recent Trends in Social and Behaviour Sciences (pp. 469-473). London: Taylor \& Francis Group.

Anderson, R. C., \& Bizjak, J. M. (2003). An empirical examination of the role of the CEO and the compensation committee in structuring executive pay. Journal of Banking and Finance, 27(7), 1323-1348.

Anderson, R. C., \& Reeb, D. M. (2003). Founding-Family Ownership and Firm Performance: Evidence from the S\&P 500. The Journal of Finance, 58(3), 1301-1328. https://doi.org/10.1111/1540-6261.00567

BBC News. (2012). "Why is chief executives" pay not linked to performance?". BBC News, 9 February. Retrieved from www.bbc.co.uk/news/business-16932043

BBC News. (2013). "Pay gap between executives and employees is widening”. BBC News, 18 November. Retrieved from www.bbc.co.uk/news/business-24983761

Chen, H. (2006). Board Characteristics, Ownership Structure and Executive Remuneration in China. PhD Thesis. Retrieved from http://orca.cf.ac.uk/id/eprint/54091

Coles, J. L., \& Li, Z. F. (2019). An empirical assessment of empirical corporate finance. https://doi.org/10.2139/ssrn.1787143

Coles, J. L., \& Li, Z. F. (2020). Managerial attributes, incentives and performance. The Review of Corporate Finance Studies, 9(2), 256-301. https://doi.org/10.1093/rcfs/cfaa006 
Core, J. E., Holthausen, R. W., \& Larcker, D. F. (1999). Corporate governance, chief executive officer compensation, and firm performance. Journal of Financial Economics, 51(3), 371-406.

Cybinski, P., \& Windsor, C. (2013). Remuneration committee independence and CEO remuneration for firm financial performance. Accounting Research Journal, 26(3), 197-221. https://doi.org/10.1108/ARJ-08-2012-0068

Dah, M. A., \& Frye, M. B. (2017). Is board compensation excessive?. Journal of Corporate Finance, 45(2017), 566-585. https://doi.org/10.1016/j.jcorpfin.2017.06.001

Dahya, J., Dimitrovb, O., \& McConnellc, J. J. (2008). Dominant shareholders, corporate boards, and corporate value: A cross-country analysis. Journal of Financial Economics, 87(2008), 73-100. https://doi.org/10.1016/j.jfineco.2006.10.005

Daily, C. M., \& Dalton, D. R. (1994). Corporate governance and the bankrupt firm: An empirical assessment. Strategic Management Journal, 15(8), 643-654. https://doi.org/10.1002/smj.4250150806

Daily, C. M., Johnson, J. L., Ellstrand, A. E., \& Dalton, D. R. (2017). Compensation Committee Composition as a Determinant of CEO Compensation. Academy of Management Journal, 41(2), 209-220. https://doi.org/10.5465/257103

Dang, C., Li, Z. F., \& Yang, C. (2018), Measuring firm size in empirical corporate finance. Journal of Banking and Finance, 86(2018), 159-176. https://doi.org/10.1016/j-jbankfin.2017.09.006

Dogan, E., \& Smyth, R. (2002). Board remuneration, company performance, and ownership concentration: Evidence from publicly listed Malaysian companies. ASEAN Economic Bulletin, 19(3), 319-347.

Duffhues, P., \& Kabir, R. (2008). Is the pay-performance relationship always positive? Evidence from the Netherlands. Journal of Multinational Financial Management, 18(1), 45-60. https://doi.org/10.1016/jmulfin.2007.02.004

Economist. (1995). Fat cats in the dock. Economist, London, 4 March.

Elloumi, F., \& Gueyié, J. (2001). CEO compensation, IOS and the role of corporate governance. Corporate Governance. 1(2), 23-33. https://doi.org/10.1108/EUM0000000005487

Firth, M., Tam, M., \& Tang, M. (1999). The determinants of top management pay. Omega, 27(6), 617-635.

Ghasemi, M., \& Ab Razak N.H. (2020). What determines executives' remuneration in Malaysia?. Asian Journal of Accounting and Governance, 13, 27-39. https://doi.org/10.17576/AJAG-2020-13-03

Graham, J. H., Li, S., \& Qiu, J. (2012). Managerial attributes and executive compensation. The Review of Financial Studies, 25(1), 144-186. https://doi.org/10.1093/rfs/hhr076

Haron, H., \& Akhtaruddin, M. (2013). Determinants of directors' remuneration in Malaysian public listed companies. Indian Journal of Corporate Governance, 6(2), 17-42. https://doi.org/10.1177/0974686220130202

Hassan, S., Theo, C. \& Evans, R. (2003). Directors' remuneration and firm performance: Malaysian evidence. Malaysian Accounting Review, 2(1), 57-67. Retrieved from http://ir.uitm.edu.my/id/eprint/13689

Hearn, B. (2013). The impact of board governance on director compensation in West Africa IPO firms. Research in International Business and Finance, 28, 82-104.

Herdan, A., \& Szczepańska, K. (2011). Directors Remuneration and Companies' Performance the Comparison of Listed Companies in Poland and UK. Foundations of Management, 3(2), 41-54. https://doi.org/10.2478/v10238-012-0041-8

Jaafar, S. B., \& James, K. (2013). Determinant of Director Remuneration in Malaysia Public Listed Companies. International Journal of Trade, Economics, and Finance, 4(6), 353-357

Jensen, M. C., \& Murphy, K. J. (1990). Performance pay and top-management incentives. Journal of Political Economy, 98(2), 225-264. https://doi.org/10.1086/261677

Jensen, M., \& Meckling, W. (1976). Theory of the firm: managerial behavior, agency costs, and ownership structure. Journal of Financial Economics, 3(3), 305-360.

Kabir, R. (2008). International perspectives on executive compensation. Journal of Multinational Financial Management, 18(1)1-3.

Khoo, D. (2018, July 18). Sapura Energy's Shahril survives ouster move at AGM. The Star. Retrieved from https://www.thestar.com/business-news/2018/07/18/institutional-shareholders-unhappy-with-sapura-energys-remuneration/

Lee, S. P., \& Isa, M. (2015), Directors' remuneration, governance and performance: the case of Malaysian banks. 
Managerial Finance, 41(1), 26-44. https://doi.org/10.1108/MF-08-2013-0222

Li, F. (2016). Endogeneity in CEO power: A survey and experiment. Investment Analysis Journal, 45(3), 149-162. https://doi.org/10.1080/10293523.2016.1151985

MCCG. (2002). Malaysian Code on Corporate Governance, Securities Commission of Malaysia.

MCCG. (2007). Malaysian Code on Corporate Governance, Securities Commission of Malaysia.

MCCG. (2012). Malaysian Code on Corporate Governance, Securities Commission of Malaysia.

MCCG. (2017). Malaysian Code on Corporate Governance, Securities Commission of Malaysia.

Muslu, V. (2005). Effect of board independence on incentive compensation and compensation disclosure: Evidence from Europe. Thesis, Massachusetts Institute of Technology. USA

Ndzi, E. (2016). Directors' pay regulation: one goal two approaches. International Journal of Law and Management, 58(3), 337-352. https://doi.org/10.1108/IJLMA-07-2015-0034

Ndzi, E. (2017). The impact of the Salomon principle on directors' remuneration in the UK. International Journal of Law and Management, 59(2), 257-270. https://doi.org/10.1108/ijlma-11-2015-0058

Nelson, J., Gallery, G., \& Percy, M. (2010). Role of corporate governance in mitigating the selective disclosure of executive stock option information. Accounting and Finance, 50(3), 685-717. https://doi.org/10.1111/j.1467-629X.2009.00339.x

Nyambia, H. S., \& Hamdan, H. (2018). The scantness of the effect of corporate governance mechanisms on executive directors' remuneration in small listed companies: Evidence from Malaysia, Social Responsibility Journal, 14(4), 934-949. https://doi.org/10.1108/SRJ-01-2017-0014

Ozkan, A. (2008). Institutional investors and director pay: An empirical study of UK companies. Journal of Multinational Financial Management, 18(1), 16-29. https://doi.org/10.1016/j.mulfin.2007.06.001

Pearce, J. P. II, \& Zahra, S. A. (1991). The relative power of CEOs and boards of directors: Associations with corporate performance. Strategic Management Journal, 12(2), 135-153. https://doi.org/10.1002/smj.4250120205

Sunday Times. (1995). Derailing the gravy train. Sunday Times, Perth, 22 January.

The Star. (2018), Transparency in remuneration Malaysia Inc 2.0. The Star, 21 July. Retrieved from https://www.thestar.com.my/business/business-news/2018/07/21/transparency-in-remuneration-malaysia-inc-20 -silver-lining-in-the-dark-cloud

The Sundaily. (2015). Bumi Armada explains big jump in payments to directors. The Sundaily, 9 June. Retrieved from https://www.thesundaily.my/archive/1452944-GSARCH313802

Viviers, S. (2016). Executive remuneration in South Africa: key issues highlighted by shareholders activists. African Journal of Business Ethics, 9(1), 1-28.

Ya'acob, N. S. (2016). CEO Duality and Compensation in the Market for Corporate Control: Evidence from Malaysia. Procedia Economics and Finance, 35, 309- 318. https://doi.org/10.1016/S2212-5671(16)00039-3

Yatim, P. (2012). Board room pay, performance and corporate governance in Malaysia. The Business \& Management Review, 2(2), 36-51.

Zakariah, Z. (2018, July 19). Sapura Energy Bhd: Discontent over CEO Remuneration. New Straits Times. Retrieved from https://www.nst.com.my/business/2018/07/392083/institutional-investors-unhappy-over-shahrils-remuneration

Zhou, X. (2000). CEO pay, firm size, and corporate performance: Evidence from Canada. Canadian Journal of Economics, 33(1), 213-251. https://doi.org/10.1111/0008-4085.00013

\section{Copyrights}

Copyright for this article is retained by the author(s), with first publication rights granted to the journal.

This is an open-access article distributed under the terms and conditions of the Creative Commons Attribution license (http://creativecommons.org/licenses/by/4.0/). 